\title{
Achieving Quality Output in the Nigerian Banking Sector through Total Quality Management Skills
}

\author{
Olanrewaju Makinde Hassan ${ }^{1}$ \\ ${ }^{1}$ Department of Business Administration, Faculty of Management Sciences, Kogi State University, Anyigba, Kogi \\ State, Nigeria \\ Correspondence: Olanrewaju Makinde Hassan, Department of Business Administration, Faculty of Management \\ Sciences, Kogi State University, Anyigba, Kogi State, Nigeria. E-mail: Olanrewajuhassan75@yahoo.com, \\ olanrewaju.hassan@zenithbank.com \\ Received: August 15, 2013 \\ Accepted: January 14, $2014 \quad$ Online Published: January 16, 2014 \\ doi:10.5430/ijba.v5n1p99 \\ URL: http://dx.doi.org/10.5430/ijba.v5n1p99
}

\begin{abstract}
This study is on achieving Quality output in the Nigerian banking sector through total quality management skills. The study is motivated by the need to challenge the banking sector in Nigeria to employ best practice like other global banks around the world. The study made use of primary data sourced from the customers of eight (8) selected banks through administering of questionnaire. Their responses were tested using appropriate statistical tools like the simple percentage and the Chi-square research techniques; our study revealed that although quality output can be achieved in the Nigerian banking sector using total quality management skills but for the existence of obvious impediments that have made it look impossible. Therefore, the study recommended that such impediments like corrupt practices, ignorance, e-network failure and power problem be promptly tackled and eliminated to give the Nigerian banks competitive edge amongst top banks the world over.
\end{abstract}

Keywords: total quality management, output, banking sector, best practice, competitive edge

\section{Introduction}

We now live in a very competitive and innovative world; it is so much that what use to be acceptable as standard yesterday has suddenly become obsolete today. Competition is one of the most important factors in running a business in the world economy today. For almost every product or service ever designed, there is more than one organization trying to make a sale. Price is, of course, one of the major issues in whether a sale is made or lost. If the cost of production of goods or services results in high prices, a firm may not be competitive. But another factor that a customer considers before buying a product is quality. In fact, a reputation for producing quality products is often a major marketing issue.

Quality is not just of concern in manufactured products, it is important in banking, hospital care, education, air travel, auto repair, postal delivery services and a host of other firms in the service industry. Total quality management (TQM) is the commonly used term for stressing quality within an organization. TQM uses a systems perspective because it is not a program for one department, but a responsibility of everyone in the organization. To keep quality at the desirable levels, all firms employ the concept of quality control. Quality control (QC) is important not just in the production or transformation process, but earlier at the design stage and later at the service stage as well. One of the major roles of the operations manager is to make sure his or her firm can deliver a quality product to the right place at the right time at the right price (Heizer and Render, 1991: 734).

\subsection{Statement of Problem}

Total Quality is now widely recognized and accepted as an effective management tool for improving organizational performance which in return offers benefits to customers, employees and other stakeholders (Ejumudo, 2012). Likewise, it is the way of managing for the future, and is far wider in its application than just assuring product or service quality - it is a way of managing people and business processes to ensure complete customer satisfaction at every stage, internally and externally. TQM, combined with effective leadership, results in an organisation doing the right things right, first time. 
The banking sector in recent years has been going through series of changes and transformation targeted at improving the quality of banking business in Nigeria. These changes in the Nigerian banking industry have brought about increased aggressive competition. To understand and take advantage of the changes, which may be opportunities or threats, Nigerian banks need to understand the important factors shaping the industry and the relevant strategic decisions to be taken. These strategic decisions must take into account the relevant competitive, economic, political, regulatory, legal, technological and socio-cultural factors, among others in the Nigerian business environment. A total quality management (TQM) culture is a strong culture in which values are directed toward the strategic purpose of aligning people, processes and resources to create value for customers through continuous improvement for strategic purposes. Do we have TQM culture in our banks? What are the characteristics of good quality service in the Nigerian Banking Industry?

How do we determine good quality service in our banks these days: What are the problems hindering the production of good quality service in Nigerian banks? These are the issues this paper seeks to proffer answers to.

\subsection{Objectives of the Study}

The objectives of this study are mainly to:

1.) Examine if quality output in the Nigerian banking sector can be attained through total quality management skills i.e. to test the viability of the success of the principles of total quality management in the Nigerian banking sector.

2.) To find out if there are impediments militating against the use of total quality management in the Nigerian banking industry.

\subsection{Research Hypotheses}

The hypotheses that shall guide this study are as stated below:

\section{Hypothesis one}

Null Hypothesis: Quality output cannot be achieved in the Nigerian banking sector through total quality management skills.

Alternative Hypothesis: Quality output can be achieved in the Nigerian banking sector through total quality management skills.

\section{Hypothesis two}

Null Hypothesis: There are no impediments militating against the use of total quality management in the Nigerian banking industry.

Alternative Hypothesis: There are impediments militating against the use of total quality management in the Nigerian banking industry.

\section{Literature Review and Empirical Study}

\section{Total Quality Management: A Conceptual Explanation}

Total quality management (TQM) can be defined as a strategy for improving organizational performance through the commitment of all employees to the full satisfaction of the agreed customer requirements at the lowest overall cost through the continuous improvement of products and services, organizational processes and people involved. Total quality management is also a set of management practices throughout the organization geared towards ensuring that the organization consistently meets or exceeds customer requirements. The total quality management is equally a method by which management and employees can become involved in the continuous improvement of the production of goods and services. Total quality management is, in fact, a management approach that originated in Japanese industry in $1950 \mathrm{~s}$ and has steadily become more popular since the early 1980s. Total quality management is therefore a management philosophy that seeks to integrate all organizational functions (human resource, marketing, finance, design, engineering, production, customer service etc) to focus on meeting customer needs and organizational objectives (Kanter 2003). To him, the simple objective of TQM is to do the right things the first time and every time.

Stoner et al (2005) defined TQM as "an organizational cultural commitment to satisfying customers through the use of an integrated system of tools, techniques, and training. TQM involves the continuous improvement of organizational process, resulting in high-quality products and services. Iyayi (2004) sees TQM as route to and philosophy of excellence where excellences in organization means providing product and services that have good quality to a high degree. TQM as a route of excellence implies conscious, formalized and systematic process of seeking, advancing and 
organizational purpose of satisfying the customers and consequently improving the overall together performance of the organization. TQM is therefore a total orientation in doing things which required a complete reawakening on the part of both the management and the work force. TQM works when it is completely integrated into the culture of the organization and it becomes a way of life and an endless journey practiced by all. It ought to be a total culture driven and modelled by a perfect leadership. TQM means focusing on the production of increasingly better products and services at progressively more competitive prices. It means doing things right in organizations on the first try rather than making and correcting mistakes. Gbodimowo (1998) equally stressed that total quality management as 'a service management led comparative initiative, intended to improve effectiveness and to build quality into the goods and services delivered, with the involvement of the whole workforce and a commitment to do the right things correctly.

In the same light, Ukaegbu (1995) posited TQM "as a strategy for improving organizational performance through the commitment of all employees to fully satisfying agreed customer requirements at the lowest overall cost through the continuous improvement of products and services, business process and the people involved. Total quality management (TQM) is both a management philosophy and a practical working process for achieving distinctive quality products and services at the lowest cost to the organizations which places the customer(s) on the highest utility curve (Macdonald 1999). According to Milakovich (1991:5) and Swiss (1992:12) TQM is now becoming recognized as a generic management tool that is applicable in public sector organizations. As its name connotes, TQM is an attempt to maximize quality within and through an organization. TQM involves the organization's long-term commitment to the continuous improvement of quality; throughout the organization and with the active participation of all members at all levels, to meet and exceed customer expectations. Total Quality Management (TQM) is a philosophy which combines organization's teamwork with the quality management philosophies of Deming and Juran. It requires that various departments be seen as "internal" customers as well as considering the needs and requirements of those outside who are external customers. Total quality management is a way of life for organizations and it must be initiated and monitored strategically by top management whose involvement and participation is critical to its success and discernible by others down the organizational ladder. Attempt to implement TQM fails because top management pays lip service. Such level of commitment will necessarily engender support and cooperation by other organizational members. Finally, structures, mechanisms and action vehicles are needed to engineer change through a well crafted and designed, appropriately implemented and adequately evaluated institutionalized total quality management strategies.

Stevenson (2005: 398) refers to the term total quality management (TQM) as quest for quality organizations. According to him, there are three key philosophies in this approach. One is a never-ending push to improve, which is referred to as continuous improvement; the second is the involvement of everyone in the organization; and the third is the goal of customer satisfaction, which means meeting or exceeding customer expectations. Again, total quality management is a philosophy of collective responsibility and doing it right at the first time as against traditional management that believes in discovering faults and remedying them. In fact, the classical management theory regards the customer and suppliers of the organization as external environment while TQM conceives the organization as being generally boundary-less because these stakeholders are included in TQM as external members of the organization. Their actions in relation to the operations of the organization are viewed as part of organizational processes. TQM involves the organization's long-term commitment to the continuous improvement of quality; throughout the organization and with the active participation of all members at all levels, to meet and exceed customer expectations. Total Quality Management (TQM) is a philosophy which combines organization's teamwork with the quality management philosophies of Deming and Juran.

Essentially too, Stahl (1995) opined that total quality management is a management tool which adopts a system approach to management that aims to continuously increase value to customers by designing and continuously improving organizational processes and systems. MacDonald (1999) stressed that TQM is a total commitment to quality. The core of Total Quality Management is the customer-supplier interface, both externally and internally. Williams (2007:591) posited that Total Quality (TQM) is an integrated organization-wide strategy for improving product and service quality. He maintains that TQM is not a specific tool or technique. Rather, TQM is a philosophy or overall approach to management that is characterized by three principles: customer focus and satisfaction continuous improvement and team work. Total quality management is a deviation from traditional management in several respects. First, quality is seen as an investment that is aimed at improving quality that is always well designed and implemented, unlike traditional management that recognize quality as a cost and therefore very expensive. Secondly, the former is proactive and seeks to prevent ugly incidence, while the latter is reactive and seeks to remedy a situation after it has occurred. Total quality management presupposes defect or error free processes and activities through continuous improvement, unlike traditional management that accepts and accommodates defects. 


\section{Characteristics of TQM}

A study by Ngo posted on Ezinearticles.com put forward that; TQM is a new method of quality management involving many levels and processes of different functions but requiring an integrated cooperation.

The study also proposed the followings as characteristics of TQM:

1. Target: In TQM the most important target to achieve is quality. Quality policy must be set toward customer. Meeting customers' needs mean satisfying every customer requirement but not trying to reach quality standards set before. Never stop innovating; never stop perfecting the quality is one of the most important principles of TQM.

2. Scope: to ensure the quality of product and service, TQM system requires the extending of production process to suppliers and sub-contractors. Normally, the trading of material in production may account for $70 \%$ of final product cost (depend on types of product). Therefore, to ensure the quality of the input material, it is necessary to set up specific standards for each type of material to control its quality. It is also necessary to change the method of placing order to make it suitable with the production process.

3. Form: instead of controlling the quality of the finished product (after production), TQM sets up plans and programs to supervise and prevent problems right before the production process. Statistical tools are used to supervise, quantitatively analyze the results as well as factors affecting the quality, consider the reasons and take appropriate prevention methods.

4. Basis of TQM system: the basis of TQM practice in the company is Human. Talking about quality, people usually think about the product quality. But it is the quality of employees that is the main concern of TQM. Of the three factors Business, which are hard factor (machines, equipments, money...), Soft factor (methods, secrets, information...) and Human factor, Human is of the first concern to TQM. The basic principle for implementation of TQM is that the qualification of employees is developed fully and integratedly through training, delegation and assignment.

5. Organization: TQM system is cross organized and functioned in order to manage, integratedly corporate with different activities of the system and facilitate group working. The implementation of TQM requires the participation of high and middle level managers. A proper organization will help duties to be assigned clearly. Thus, TQM needs new management model, with different characteristics from the previous model.

6. Management skill and tools: Methods to implement must be based on the principle "do correctly at the beginning" in researching and designing to minimize economic cost. Strictly apply DEMMING circle (PDCA) to make foundation for the continous quality improvement. Source: http://EzineArticles.com/?expert=Ngo_Vinet.

\section{The Banking industry in Nigeria}

The term bank is generally understood as an institution that holds a banking license granted by financial supervision authorities. Under the authorities, the bank conducts the most fundamental banking services like accepting deposits and making loans and other financial service (Wikipedia, http://en.wikipedia.org/wiki/Bank). According to Cowling and Newman

(1995: 25-41), service quality has been widely used to evaluate the performance of banking services. Nowadays, with the development of information technology, customers increasingly expect higher services in this information age. At the same time, most of them are becoming more time conscious and wanting more convenience (Kotler and Keller, 2006).

Resulting from the deregulation and liberalization of the Nigerian banking industry, the industry environment has changed in many ways: before 1987, there was little or no competition because the monetary authorities restricted entry, with the concentration of activities on four largest banks. In 1987, following the introduction of financial liberalization, entry barriers were relaxed and interest rates were decontrolled which initiated activities in the market, this lasted for few years as the licensing of new banks was stopped in 1993, while interest rate regulation was reintroduced in 1994. In 1997, interest rate deregulation was re-implemented while entry restriction was again relaxed in 1999 (Asogwa, 2004: 637-667).

At the same period, a lot of structural reforms took place in the Nigerian banking market. There were a significant number of bank closures, takeover of management and control by the Central Bank of Nigeria (CBN) and the Nigeria Deposit Insurance Corporation (NDIC). As a result of the process of consolidation, the number of banks in Nigeria shrank by approximately 22 percent between 1997 and 1999 and by 72 percent between 2000 and 2005 . 
Other important developments arising from the consolidation include the conversion of some banks to public limited liability companies and the introduction of universal banking since 2001 Asogwa, 2004: 637-667).

These changes in the Nigerian banking industry have brought about increased aggressive competition. To understand and take advantage of the changes, which may be opportunities or threats, Nigerian banks need to understand the important factors shaping the industry and the relevant strategic decisions to be taken. These strategic decisions must take into account the relevant competitive, economic, political, regulatory, legal, technological and socio-cultural factors, among others in the Nigerian business environment.

\section{Research Methodology}

\subsection{The Research Design}

The approach adopted in the execution of the study was a survey design. The researcher chose survey design as it is one method where a group of people is studied by collecting information from them. Moreso, this type of design specified how the researcher's data were collected and analyzed. So, the design was specified to use questionnaire and oral interview. This survey was used by the researcher to source for his primary data.

\subsection{Research Sample and Sampling Techniques}

The population of the study constitutes the entire banking industry and its staff. However, the impossibility of including all the members of the population makes sampling imperative. As a result, the study concentrated on about $38.09 \%$ of the existing 21 post merger mega banks i.e. eight (8) banks; they include Diamond Bank Plc, First Bank Plc, Fidelity Bank Plc, Guaranty Trust Bank, United Bank for Africa Plc, Union Bank Plc, Main Street Bank Plc, Zenith Bank Plc and their customers formed our focus for this study

The researcher sampled only two hundred and forty (240) customers of eight (8) banks located in Lokoja the Kogi state capital out of a total of about eighteen (18) mega banks in Lokoja metropolis. Our focus was on four (4) old generation banks; i.e. First bank, Union bank, UBA, Mainstreet bank and four (4) new generation banks i.e. Diamond bank, Fidelity bank, Guaranty Trust bank, Zenith bank and their literate customers going by the nature of the study. Thirty (30) questionnaire were administered to thirty (30) customers of each of the eight selected banks. The researcher sampled this number because it was not possible to use the entire banks in the state and their customers.

In the sampling of the population for this study, the researcher used simple random sampling technique. The technique provided each member of the banks' customers equal and independent chance of being selected or included in the sample. Another reason why the researcher chose the technique is that it is a simple and easy probability sampling technique in terms of conceptualization and application. The researcher shared the questionnaire in offices and public places, likewise the oral interview.

\subsection{Sources of Data}

The researcher collected data for this study from both primary and secondary sources. She used questionnaire and oral interview to collect his primary data, while she consulted books, journals, magazines, newspapers and other documents not within the mentioned categories to source for her secondary data. Secondary data were sourced from both public and private resourced centres like libraries and printed materials.

\subsection{Data Analysis}

All the data collected from primary source through questionnaires and oral interview were statistically presented and analysed. Frequency and tabular percentage forms were used for data presentation while Chi-square $\mathrm{T}$ - test was used to test and analyse some selected hypotheses as not all were analysed due to time constraints.

\section{Presentation and Analysis of Data}

In all, a total of 240 questionnaire were administered, and a total of 220 was duly filled and returned, and it is these returned questionnaire that we are going to do our analysis and inferences.

\subsection{Presentation of Data}

The data for this study is hereby presented and analyzed below using the Simple Percentage and the Chi-Square statistical technique for test of Hypotheses as appropriate. 
Table 1. Sex distribution of the respondents

\begin{tabular}{lll}
\hline Gender & No of Respondents & Percentage (\%) \\
\hline Male & 125 & 48.7 \\
\hline Female & 95 & 51.2 \\
\hline Total & $\mathbf{2 2 0}$ & $\mathbf{1 0 0}$ \\
\hline
\end{tabular}

Source: Field Work 2012

Table 1 above shows that 125 respondents representing $48.7 \%$ of the total respondents are male while 95 respondents representing $51.4 \%$ are female.

Table 2. Age distribution of respondent

\begin{tabular}{lll}
\hline Age Distribution & No of Respondents & Percentage (\%) \\
\hline $18-20$ & 25 & $11 \%$ \\
\hline $25-30$ & 65 & $30 \%$ \\
\hline $31-40$ & 75 & $34 \%$ \\
\hline $41-50$ & 35 & $16 \%$ \\
\hline 50 and above & 20 & $9 \%$ \\
\hline Total & $\mathbf{2 2 0}$ & $\mathbf{1 0 0}$
\end{tabular}

Source: Field work 2012

Table 2 above show that 25 respondent representing $11 \%$ of the total respondents are between $18-25$ years, 65 respondents representing $30 \%$ of the total respondents are between $26-30$ years, 75 respondents representing $34 \%$ of the total respondents are between 31-40 years, 35 respondents representing $16 \%$ of the total respondents are between 41-50 years while 20 respondents representing $9 \%$ of the total respondents are 50 and above.

Table 3. Occupational distribution of respondents

\begin{tabular}{lll}
\hline Occupation & No of respondents & Percentage (\%) \\
\hline Farmers & 16 & $7 \%$ \\
\hline Traders & 74 & $34 \%$ \\
\hline Civil servant & 82 & $37 \%$ \\
\hline Craftwork & 25 & $11 \%$ \\
\hline Others & 23 & $11 \%$ \\
\hline Total & $\mathbf{2 2 0}$ & $\mathbf{1 0 0}$ \\
\hline
\end{tabular}

Source: Field Work, 2012

From Table 3 above, 16 respondents representing $7 \%$ of the total respondents are farmers, 74 respondents representing $34 \%$ of the total respondents are traders, 82 respondents representing $37 \%$ of the total respondents are civil servants, 25 respondents representing $11 \%$ of the total respondents are craft workers while 23 respondents representing $11 \%$ of the total respondents are others.

Table 4. Respondents' response on whether they agree that quality output can be achieved through total quality management system in the Nigerian banking industry

\begin{tabular}{lllll}
\hline \multirow{2}{*}{ Option } & \multicolumn{2}{c}{ Respondents } & Total & Percentage (\%) \\
\cline { 2 - 3 } & Male & Female & & \\
\hline Strongly Agree & 67 & 40 & 107 & $49 \%$ \\
\hline Agree & 43 & 32 & 75 & $36 \%$ \\
\hline Strongly disagree & 3 & 10 & 13 & $4 \%$ \\
\hline Disagree & 5 & 8 & 13 & $6 \%$ \\
\hline Undecided & 7 & 5 & 12 & $5 \%$ \\
\hline Total & 125 & 95 & 220 & 100 \\
\hline
\end{tabular}

Source: Field Work 2012 
From Table 4 above, it shows that 107 respondents representing $49 \%$ strongly agreed that quality output can be achieved through total quality management skills, 80 respondents indicates $36 \%$ agreed to that as well; but 8 respondents representing 4\% strongly disagreed, 13 respondents representing $6 \%$ merely disagreed while 12 respondents representing $5 \%$ were undecided.

Table 5. On whether they agree that the Nigerian banks have adopted total quality management system

\begin{tabular}{lllll}
\hline \multirow{2}{*}{ Option } & \multicolumn{2}{l}{ Respondents } & Total & Percentage (\%) \\
\cline { 2 - 3 } & Male & Female & & \\
\hline Strongly Agree & 15 & 22 & 37 & $17 \%$ \\
\hline Agree & 40 & 37 & 77 & $35 \%$ \\
\hline Strongly disagree & 32 & 41 & 73 & $33 \%$ \\
\hline Disagree & 12 & 11 & 23 & $10 \%$ \\
\hline Undecided & 6 & 4 & 10 & $5 \%$ \\
\hline Total & $\mathbf{1 2 5}$ & $\mathbf{9 5}$ & $\mathbf{2 2 0}$ & $\mathbf{1 0 0}$ \\
\hline
\end{tabular}

Source: Field Work 2012

The result in Table 5 above indicates that 37 respondents representing $17 \%$ strongly agreed that the Nigerian banks have adopted total quality management system, 77 responses from the respondents merely agreed which amount to $35 \%, 73$ respondents strongly disagreed which indicated 33\%, 23 respondents representing $10 \%$ disagreed while 10 respondents representing $5 \%$ were undecided.

Table 6. On whether total quality management have impacted positively on banking services in Nigeria

\begin{tabular}{lllll}
\hline \multirow{2}{*}{ Responses } & \multicolumn{2}{l}{ Respondents } & Total & \multirow{2}{*}{ Percentage (\%) } \\
\cline { 2 - 3 } & Male & Female & & \\
\hline Strongly Agree & 75 & 60 & 135 & $61 \%$ \\
\hline Agree & 25 & 21 & 46 & $20 \%$ \\
\hline Strongly disagree & 10 & 7 & 17 & $8 \%$ \\
\hline Disagree & 5 & 5 & 10 & $5 \%$ \\
\hline Undecided & 5 & 7 & 12 & 6 \\
\hline Total & 125 & 95 & 220 & 100 \\
\hline
\end{tabular}

Source: Field Work 2012

From the Table 6 above, it shows that 135 respondents indicating $61 \%$ strongly agree, 46 respondents representing $20 \%$ agree that total quality management have impacted positively on bank services in Nigeria, 17 respondents representing $8 \%$ strongly disagree to it while 10 respondents representing 5\% disagree and $6 \%$ representing 12 respondents were undecided

Table 7. On to what extent are they satisfied with services banks renders to their customers in relation to total quality management

\begin{tabular}{lllll}
\hline \multirow{2}{*}{ Option } & \multicolumn{2}{l}{ Respondents } & Total & Percentage (\%) \\
\cline { 2 - 3 } & Male & Female & & \\
\hline Very High extent & 13 & 12 & 25 & $11 \%$ \\
\hline High extent & 22 & 17 & 39 & $18 \%$ \\
\hline Low extent & 65 & 61 & 126 & $57 \%$ \\
\hline Very low extent & 15 & 5 & 20 & $9 \%$ \\
\hline Not at all & 6 & 4 & 10 & $5 \%$ \\
\hline Total & 125 & 95 & 220 & 100 \\
\hline
\end{tabular}

Source: Field Work 2012

Table 7 above indicates that 25 respondents representing $11 \%$ says to a very high extent they are satisfied with services banks render to their customers in relation to total quality management, $18 \%$ representing 39 respondents says to a high extent while 126 respondents indicating $57 \%$ believes it is to a low extent, 20 respondents representing $9 \%$ says it is to a very low extent and 10 respondents representing $5 \%$ were undecided. 
Table 8 . On the viability of the success of the total quality management principles in the Nigerian banking industry

\begin{tabular}{lllll}
\hline \multirow{2}{*}{ Option } & \multicolumn{2}{l}{ Respondents } & Total & Percentage (\%) \\
\cline { 2 - 3 } & Male & Female & & \\
\hline Strongly Agree & 80 & 57 & 137 & $62 \%$ \\
\hline Agree & 32 & 10 & 42 & $19 \%$ \\
\hline Strongly disagree & 10 & 15 & 25 & $11 \%$ \\
\hline Disagree & 7 & 3 & 10 & $5 \%$ \\
\hline Undecided & 1 & 5 & 6 & $3 \%$ \\
\hline Total & $\mathbf{1 2 5}$ & $\mathbf{9 5}$ & $\mathbf{2 2 0}$ & $\mathbf{1 0 0}$
\end{tabular}

Source: Field Work 2012

Table 8 above shows that 137 respondents strongly agreed representing 38\% that the total quality management principles can thrive successfully in the Nigerian banking industry, responses from 42 respondents representing 19\% agrees, 25 respondents strongly disagreed which indicate $11 \%$, respondents 10 disagreed which constitute $5 \%$ while 6 respondents were undecided which represent $3 \%$.

Table 9. On whether there are challenges and impediments militating against the adoption of total quality management by Nigerian banks

\begin{tabular}{lllll}
\hline \multirow{2}{*}{ Responses } & \multicolumn{2}{l}{ Respondents } & Total & \multirow{2}{*}{ Percentage (\%) } \\
\cline { 2 - 3 } & Male & Female & & \\
\hline Strongly Agree & 90 & 75 & 165 & $75 \%$ \\
\hline Agree & 13 & 5 & 18 & $8 \%$ \\
\hline Strongly disagree & 7 & 8 & 15 & $7 \%$ \\
\hline Disagree & 8 & 6 & 14 & $6 \%$ \\
\hline Undecided & 2 & 6 & 8 & $4 \%$ \\
\hline Total & 125 & 95 & 220 & 100 \\
\hline
\end{tabular}

Source: Field Work 2012

Table 9 above indicates that 165 respondents representing $75 \%$ strongly agree that there are challenges and impediments militating against the adoption of the total quality management by Nigerian banks, 18 respondents agree to it representing $8 \%, 15$ respondents strongly disagree account to $7 \%$ and 14 respondents representing $6 \%$ disagree while 8 responses which indicate $4 \%$ are undecided.

Table 10. On which of these impediment is most prominent among other impediments to total quality management in banking industry in Nigeria

\begin{tabular}{lllll}
\hline \multirow{2}{*}{ Option } & \multicolumn{2}{l}{ Respondents } & \multirow{2}{*}{ Total } & \multirow{2}{*}{ Percentage (\%) } \\
\cline { 2 - 3 } & Male & Female & & \\
\hline Corruption practices & 35 & 20 & 55 & $25 \%$ \\
\hline Ignorance of TQM & 22 & 20 & 42 & $19 \%$ \\
\hline Insufficient branches & 34 & 22 & 56 & $26 \%$ \\
\hline Network failure & 13 & 12 & 25 & $11 \%$ \\
\hline Power failure & 21 & 21 & 42 & $19 \%$ \\
\hline Total & $\mathbf{1 2 5}$ & $\mathbf{9 5}$ & $\mathbf{2 2 0}$ & $\mathbf{1 0 0}$ \\
\hline
\end{tabular}

Source: Field Work 2012

Table 10 above shows that of all the impediments to total quality management in Nigerian banking industry 55 respondents representing $25 \%$ says corrupt practices is more pronounced, 42 respondents representing $19 \%$ believe it is ignorance of TQM, 56 respondents strongly disagree representing $26 \%$, whereas 25 respondents indicating $11 \%$ opted for e-network failure while 42 respondents representing 19\% stayed with power failure as the most challenging impediment. 


\subsection{Analysis of Data}

In analysing our data, we shall recall our statement of hypotheses one and two, and also sought out presented tables that have direct bearing on stated objectives and hypotheses.

Recall statement of hypothesis one and two

\section{Hypothesis to be tested}

\section{Hypothesis one}

Null Hypothesis: Quality output cannot be achieved in the Nigerian banking sector through total quality management skills.

Alternative Hypothesis: Quality output can be achieved in the Nigerian banking sector through total quality management skills.

With reference to Table 4 presented as thus, from Table 4 above, it shows that 55 respondents representing $44 \%$ strongly agreed that research methodology is very relevant to the field of management sciences, 43 respondents implying $34 \%$ agreed to that as well; but 14 respondents representing $11 \%$ strongly disagreed, 5 respondents representing $4 \%$ merely disagreed while 8 respondents representing $7 \%$ were undecided.

Note: Based on the respondents' responses we can infer that, research methodology is relevant to the field of management sciences. The implication is that the use of research methodology to researchers in the field of management science has been deemed very important and acceptable in most research study.

Furthermore, using the Chi-Square research technique formula to test our stated hypotheses with the content of Table 5 as well, we have:

\begin{tabular}{lllllll}
\hline Category & $\begin{array}{l}\text { Strongly } \\
\text { agree }\end{array}$ & Agree & Disagree & $\begin{array}{l}\text { Strongly } \\
\text { Disagree }\end{array}$ & Undecided & Total \\
\hline Male & 67 & 43 & 3 & 5 & 7 & $\mathbf{1 2 5}$ \\
\hline Female & 40 & 32 & 10 & 8 & 5 & $\mathbf{9 5}$ \\
\hline Total & $\mathbf{5 5}$ & $\mathbf{4 3}$ & $\mathbf{1 3}$ & $\mathbf{1 3}$ & $\mathbf{1 2}$ & $\mathbf{2 2 0}$ \\
\hline
\end{tabular}

The formula for the computation of Chi-square $\left(\mathrm{x}^{2}\right)$ is given below:

The Chi-square method denoted by; $\mathrm{X}^{2}=\frac{\sum(f o-f e)^{2}}{f e}$

Computed result is presented in a tabular form as below:

\begin{tabular}{lcccccc}
\hline VARIABLES & N & T Cal. & T Crit. & df & Prob. & Remark \\
\hline Male & 125 & & & & & \\
\hline Female & 95 & 9.53 & 7.78 & 4 & 0.5 & Reject $\mathrm{H}_{\mathrm{o}}$ \\
\hline Total & 220 & & & & & \\
\hline
\end{tabular}

Source: Researcher's X ${ }^{2}$ Calculation, 2012

Decision making: from the chi-square research technique, we observed that the calculated result is greater than the table result at the $10 \%$ level of significance i.e. $9.09>7.78$. Therefore, we reject the null hypothesis that research methodologies are not relevant to the field of Management sciences and accept the alternative that research methodologies are relevant to the field of Management sciences. This result corroborated with that obtained in Table 5 above using the simple percentages.

\section{Hypothesis two}

Null Hypothesis: There are no impediments militating against the use of total quality management in the Nigerian banking industry.

Alternative Hypothesis: There are impediments militating against the use of total quality management in the Nigerian banking industry.

Table 9 above indicates that 165 respondents representing 75\% strongly agree that there are challenges and impediments militating against the adoption of the total quality management by Nigerian banks, 18 respondents agree to it representing $8 \%, 15$ respondents strongly disagree account to $7 \%$ and 14 respondents representing $6 \%$ disagree while 8 responses which indicate $4 \%$ are undecided. 
Note: Based on the respondents' responses we can infer that, in as much as total quality management system is practicable in the Nigerian banking industry given the right environment but there are impediments that are serving as clog in the wheel of its implementation. Prominent among these impediments according to our study are corrupt practices, ignorance, e-network failure, power failure and so on. The implication is that all of these impediments have made TQM almost impossible and impracticable in the Nigerian banking industry. Although a part of its principles are currently been implemented by some of the banks but not at the level desired by global best practice. Little wonder, it was observed recently that none of the Nigerian banks is rated among the first one thousand banks in the world.

Furthermore, using the Chi-Square research technique formula to test our stated hypotheses with the content of Table 9 as well, we have:

\begin{tabular}{lllllll}
\hline Category & $\begin{array}{l}\text { Strongly } \\
\text { agree }\end{array}$ & Agree & Disagree & $\begin{array}{l}\text { Strongly } \\
\text { Disagree }\end{array}$ & Undecided & Total \\
\hline Male & 90 & 13 & 5 & 10 & 2 & $\mathbf{1 2 5}$ \\
\hline Female & 75 & 5 & 10 & 4 & 6 & $\mathbf{9 5}$ \\
\hline Total & $\mathbf{1 6 5}$ & $\mathbf{1 8}$ & $\mathbf{1 5}$ & $\mathbf{1 4}$ & $\mathbf{8}$ & $\mathbf{2 2 0}$ \\
\hline
\end{tabular}

The formula for the computation of Chi-square $\left(\mathrm{x}^{2}\right)$ is given below:

The Chi-square method denoted by; $\mathrm{X}^{2}=\frac{\sum(f o-f e)^{2}}{f e}$

Computed result is presented in a tabular form as below:

\begin{tabular}{|c|c|c|c|c|c|c|}
\hline VARIABLES & $\mathbf{N}$ & T Cal. & T Crit. & df & Prob. & Remark \\
\hline Postgraduates & 125 & & & & & \\
\hline Undergraduates & 95 & 10.09 & 7.78 & 4 & 0.10 & Reject $\mathrm{H}_{\mathrm{o}}$ \\
\hline Total & 220 & & & & & \\
\hline
\end{tabular}

Source: Researcher's X ${ }^{2}$ Calculation, 2012

Decision making: from the chi-square research technique, we observed that the calculated result is greater than the table result at the $10 \%$ level of significance i.e. $9.09>7.78$. Therefore, we reject the null hypothesis that there are no challenges and impediments militating against the adoption of total quality management by Nigerian banks and accept the alternative that there are challenges and impediments militating against the adoption of total quality management by Nigerian banks. This result corroborated with that obtained in Table 9 above using the simple percentages.

\section{Conclusion}

Service delivery has become the true test for sustenance in business couple with the competitiveness of doing business all over world today as a result globalization. This informed the need to embrace total quality management to serve as benchmark for many businesses that desire to keep pace with time. The Nigerian banking sector is not left out in this modern trend of events. As such, the need for this paper, to examine how the total quality management can be used to attain best practices in the Nigerian banking sector. Our study reveals that best practice can be attained in the banking sector in Nigeria if the characteristics of total quality management can be strictly adhere to and observed to the later and that it will sure impact on banking service delivery in Nigeria. However, it is not without some identified challenges such as corruption, ignorance, e-network failure, power failure, communication gap and resistance to change. All these are considered to be surmountable problems and it is in wake of this that we make the following recommendations.

\section{Recommendations}

For total quality management principles to thrive in the Nigerian banking industry the followings should be adequately and promptly attended to:

- Constant and consistent staff training and retraining should be embarked upon to keep abreast with time and new developments in the global banking industry.

- Subscribing to the best available e-banking system to guard against inconsistencies in network processes and performance. 
- Provisions of customer need meeting banking service, through innovation and through giving due attention to customers satisfaction at all time by being conscious of the fact that they are in business because of the customers.

- Given the fact that total quality management system is not fixed but rather a flexible and change driven phenomena, Nigerian banks should endeavour to be flexible and not rigid in their approach to service delivery.

\section{References}

Ajayi, M. (2005). Banking Sector Reforms and Bank Consolidation: Conceptual Framework, The Bullion. Journal of CBN, 29(2), 2-10.

Akhavein, Jalai, D. Allen N. Berger, \& David Hum. (1997). The Effects of Megamergers on Efficiency and Prices: Evidence from a Bank Profit Function. Review of Industrial Organization, 12.

Akhtar, S. (2007). Pakistan: Banking Sector Reforms: Performance and Challenges. Lecture Delivered at the Graduate Institute of International Studies, Geneva, Feb. 01, 2007. Retrieved from http://econ-www.bis.org.review $1070308 \mathrm{~d} . p d f$

Berger, N. Allen. (1998). The Efficiency Effects of Bank Mergers and Acquisition: A Preliminary Look at the 1990s Data. In Y. Amihud and G. Brigham, R.F. (Eds.), Financial Management Theory and Practice (1985, 4th ed.). Bank Mergers \& Acquisitions. Dryden Press Chicago.

CBN. (2005). Guidelines and Incentives on Consolidation in the Nigeria Banking Industry. Press release - April 11, 2005 on Banking Sector Consolidation. Special Incentive to Encourage Weaker Banks.

CBN. (2005). Annual Report and Statement of Accounts for various years, Abuja, Government Printer.

Ejumudo, K.B.O. (2012). The Practicability and Efficacy of Total Quality Management in the Nigerian Public Sector: A Critical Examination. IJRASS.

First Bank of Nigeria Plc. (2009). Annual Report and Accounts.

Gordon, J. (1959, May). Dividend, Earnings and Stock Prices. Journal of Economics and Statistics, 41(1).

IMF. (2008). Reports Lewis R., D. Penchril and D.S. Sion. Advanced Financial Accounting. Pitman Publishing Ltd. London.

Iyayi, F. (2004). Philosophy of Total Quality Management. Mobil News Letter, 3(1).

Kanter, R. (2003). The Change Master. New York: Simon and Schuster Company.

MacDonald, J. (1995). Understanding Total Quality Management. Lagos: Mac-Digiton Publication.

Milakovich, M.E. (1991). Total Quality Management for Public Sector Productivity Improvement. Public Productivity and Management Review, XIV(1).

Miller, M. H., \& Modigliani F. (1961, October). Dividend, Policy, Growth and Valuation of Shares. Journal of Business, 34(4).

Mohan, R. (2005a). Financial Sector Reforms: Policies and Performance Analysis. Economic Political Weekly, Special Issue on Money, Banking and Finance, March 4, 1106-1121.

Mohan, R. (2005b). Reforms, Productivity and Efficiency in Banking: The Indian Experience. The Pakistan Development Review, 44(4, Part 1), 505-538.

Nandy, D. (2010). Banking Sector Reforms in India and Performance Evalustion of Commercial Banks, Boca Raton. Florida: Dissertation.com

Okafor, F.O. (1984). Investment Decision Evaluation of Projects and Securities, Cassel, London.

Oluyemisi, G. A. (2009, April) Quality Control of Services in the Nigerian Banking Industry. International Multi-disciplinary Journal, Ethiopia 3(3). (1984). Company Analysis and Share Valuation. NOK Publishers Enugu.

. (1985). Study of Transnational Banks in Nigeria Economy, Monography Series, No. 3, Department of Banking and Finance University of Nigeria Enugu Campus. 
Onwumere, J.U.J., \& Ogamba, E.N. (2006). Beyond the 2005 Banking Industry Consolidation Exercise in Nigeria: Some Strategic Imperatives for Enhanced Productivity. Nigerian Journal of Banking and Finance, UNEC. 6, 1-11.

Reed, E.W. (1980). Commercial Banking, Englewood.

Sanusi, L.S. (2009). Address by the Governor of the Central Bank of Nigeria, Mallam Sanusi Lamido Sanusi on Development in the Banking System in Nigeria, August 14, 2009.

Soludo, C.C. (2004). Consolidating the Nigerian Banking Industry to Meet the Challenges of the 21 st Century. Address to a special meeting of the Bankers Committee, Abuja July 06, 2004, BIS Review 43/2004 pp 1-6.

Steiss, J. (2006). Total Quality Management and Organizational Efficiency. London: Kogan Page.

Stevenson, W.J. (2005). Operations Management. New York: McGraw-Hill Company.

Swiss, J. (1992). Adapting Total Quality Management to Government. Public Administration Review, 3(2).

Ukaegbu, U. (1995). Total Quality Management Strategies. NAPECTOR, 16(2).

Williams, C. (2007). Total Quality Management. New York: Thomson Publishing Company.

Wood, O.G., \& Porter R.J. (1979). Analysis of Bank Financial Statements. Van Hostrand Reinhold Company New York.

Zenith Bank Plc. (2009). Annual Reports and Statement of Accounts. 